\title{
Potential of plant Leucosidea sericea against Propionibacterium acnes
}

\author{
Richa Sharma $^{\mathrm{a}}$, Navneet Kishore ${ }^{\mathrm{a}}$, Ahmed Hussein ${ }^{\mathrm{a}, \mathrm{b}}$, Namrita Lall ${ }^{\mathrm{a}}$ \\ ${ }^{a}$ Department of Plant Science, Faculty of Agricultural and Biological Science, University of Pretoria, Pretoria- \\ 0002, South Africa \\ ${ }^{\mathrm{b}}$ Chemistry Department, University of Western Cape, Private Bag X17, Bellville 7535, Cape Town, South Africa
}

\author{
Corresponding Author: Prof. Namrita Lall \\ Department of Plant Science, \\ Plant Science Complex, University of Pretoria, \\ Pretoria-0002, South Africa \\ E-mail: namrita.lall@up.ac.za \\ Phone: 012-420-2524; Fax: +27-12-420-6668
}

Co-authors:

Richa Sharma: richajangid5@gmail.com

Navneet Kishore: kishore.navneet6@gmail.com

Ahmed Hussein: hussss4@yahoo.com

\section{Highlights:}

- Significant anti-bacterial and antioxidant activity displayed by crude extract of Leucosidea sericea and isolated compound.

- In the present study, four known and one new compound have been isolated for the first time from ethanolic extract of $L$. sericea.

- The plant exhibited anti-inflammatory efficacy by suppressing pro-inflammatory cytokines (IL 8 and TNF $\alpha$ ).

- Electron microscopy studies proved the lethal effects of plant extract and compound $\mathbf{5}$ on the cells of $P$. acnes. 


\section{Graphical abstract}

Antibacterial bioassay of ethanol extract of Leucosidea sericea and isolated compounds against Propionibacterium acnes.

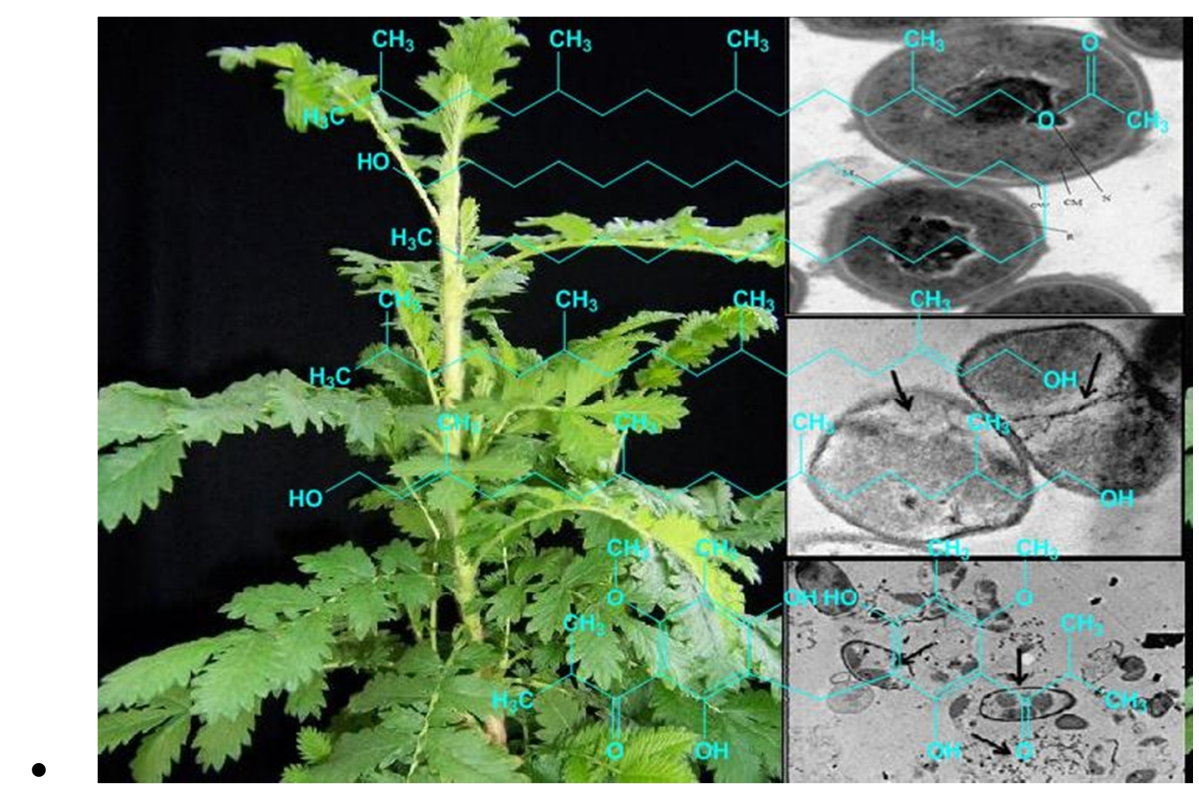

\section{Abstract}

The present study reports on the potential of Leucosidea sericea addressing acne vulgaris.

Four known compounds namely, phytol acetate, triacontanol, phytol and alpha kosin and one new compound namely, (E)-3,7,11,15-tetramethylheptadec-2-ene-1,1 7-diol have been isolated for the first time from this plant. The ethanol extract of leaves and one of the isolated compounds, alpha kosin exhibited significant minimum inhibitory concentration (with MIC values 15.7 and $1.9 \mu \mathrm{g} / \mathrm{mL}$, respectively) against acne inducing bacteria, Propionibacterium acnes. Moreover, the transmission electron micrographs showed the efflux of intracellular content of the cells of $P$. acnes caused by plant extract and alpha kosin. The ethanol extract of L. sericea exhibited significant anti-inflammatory activity by suppressing interleukin 8 (IL 8 ) and tumour necrosis factor (TNF $\alpha)$ in coculture of human U937 cells and heat killed $P$. acnes at concentrations of $25.0,12.5$ and $6.2 \mu \mathrm{g} / \mathrm{mL}$.

Keywords: Propionibacterium acnes, Leucosidea sericea, antibacterial, Interleukin 8, Tumour necrosis alpha, Transmission electron microscopy 


\section{Introduction}

Acne is an inflammatory disease caused by gram-positive bacterium Propionibacterium acnes (P. acnes). It is the most common skin disease that affects areas covering the oil glands and hair follicles usually found on the face, chest, upper arm, back and trunk (Leydon, 1997). P. acnes is an obligate anaerobic organism that has capability to metabolize sebaceous triglycerides into fatty acids inside sebaceous gland. Also, due to the increased production of sebum, thickening of epidermis at the outlet of pilosebaceous unit occurs resulting in obstruction to the flow of sebum outwards and a comedo develops (Chomnawang et al., 2012; Coenye et al., 2012). Due to increased fatty acids content, the production of various reactive oxygen species (ROS) from the damaged follicular walls lead to the release of various cytokines like interleukin 8 (IL 8) and tumour necrosis factor (TNF $\alpha$ ) as host immune response. All these events lead to inflammation and pathogenesis of the disease. The usual drugs used in the treatment of acne have various side effects. The topical antibiotics can lead to dryness, redness, irritation of skin and hypopigmentation whereas oral antibiotics can cause gastrointestinal disorders and increase the risk of venous thromboembolism (Arican et al., 2005; Shaw and Kennedy, 2007).

The plant Leucosidea sericea Eck1. \& Zeyh. (Rosaceae) is a single species of the genus Leucosidea, found in Eastern Cape, Free State and KwaZulu-Natal provinces of South Africa (Van Wyk et al., 2008). It is used against various ailments including severe inflammation of the eyes and in the treatment of ophthalmia (Aremu et al., 2010). The Zulus, a South African tribe, use the plant as an astringent in combination with other plants (Fouche et al., 2008). Earlier researchers have reported in vitro antimicrobial, antioxidant, acetyl-cholinesterase inhibitory (Aremu et al., 2011) and moderate anticancer activity (Fouche et al., 2008) of $L$. sericea. There are very few reports on the phytochemical investigation of the plant. Previous researchers have isolated two phloroglucinols, namely, aspidinol and desaspidinol from the leaves and flowers, while the presence of $\beta$-sitosterol and $\beta$-sitostenone were reported from 
the stems (Bosman et al., 2004; Nair et al., 2012). In our continuing search for bioactive molecules from plant resources, present paper describes the isolation and characterization of four long chain fatty alcohols with one phloroglucinol derivative and their anti-bacterial, antioxidant and anti-inflammatory activity.

\section{Result and discussion}

\subsection{Identification of isolated compounds}

The ethanol extract of dried and powdered leaves of L. sericea subjected to chromatographic purification resulted into isolation of five compounds 1-5 (Fig 1). Structural assessment of these compounds was characterized by Mass, ${ }^{1} \mathrm{H}$ and ${ }^{13} \mathrm{C}$ NMR spectroscopic data. Assignment of signals was facilitated by COSY, HSQC and HMBC experiments. The known compounds obtained in this study, phytol acetate (1) (Itoh et al., 2003), triacontanol (2), (Tsai et al., 2007), phytol (3) (Itoh et al., 2003), and alpha kosin (5) (Woldemariam et al., 1992) were identified by comparison of their physical and spectroscopic data with literature reports.

Compound 4 was obtained as an oily liquid from a variety of chromatographic separations. The IR spectrum (KBr) exhibited absorption bands at 3417 and 3300 (corresponding to two hydroxyl groups) along with other absorption bands at 2954 and $2849 \mathrm{~cm}^{-1}$. Elemental analysis (Found: C, 77.21\%; H, 12.93\%/requires: C, 77.24\%; H, 12.96\%) in combination with 21 carbons resonance and a molecular ion peak $[\mathrm{M}+\mathrm{H}]^{+}$observed at $\mathrm{m} / \mathrm{z} 327.3021$ in positive mode of EI-MS, established the molecular formula to be $\mathrm{C}_{21} \mathrm{H}_{42} \mathrm{O}_{2}$. A peak at 295.2727 appeared due to loss of $\left[\mathrm{M}-\mathrm{CH}_{2} \mathrm{OH}\right]$ moiety. ${ }^{1} \mathrm{H}$ NMR spectrum $(200 \mathrm{MHz}$ in $\left.\mathrm{CDCl}_{3}\right)$ of compound 4 exhibited the signal of $\mathrm{H}-2$ at $\delta 5.39(\mathrm{~J}=8)$ vicinally coupled to the two protons doublet on $\mathrm{C}-1$ at $\delta 4.15(J=8)$ and allylically to the protons on C-4 and the vinyl methyl (C-21). The methylene protons doublet at $\delta 4.15(J=8)$ showed correlation with an olefinic proton $\delta 5.39$ in ${ }^{1} \mathrm{H}-{ }^{1} \mathrm{H}$ COSY experiment suggested the presence of a double 
bond between $\mathrm{C}-2$ and $\mathrm{C}-3$. In ${ }^{13} \mathrm{C}$ NMR spectrum (50 MHz, $\mathrm{CDCl}_{3}$ ) of compound 4 , the two carbon resonance signals observed at $\delta 141.2$ and 123.9 were evidenced for olefinic carbon positioned at C-3 and C-2, respectively. The chemical shift values corresponding to protons and olefin methyl group attached to respective hetero-nuclear carbons were evidenced on the basis of HSQC spectrum. In HMBC spectrum, the proton H-2 was found to be correlated to C-3, Similarly, H-2 showed connectivity to C-4 and C-17. Also, the correlations were observed between olefin methyl protons at $\delta 1.65$ to $\mathrm{C}-2$ and C-4.

Figure 1: Structures of isolated compounds from Leucosidea sericea (1-5)

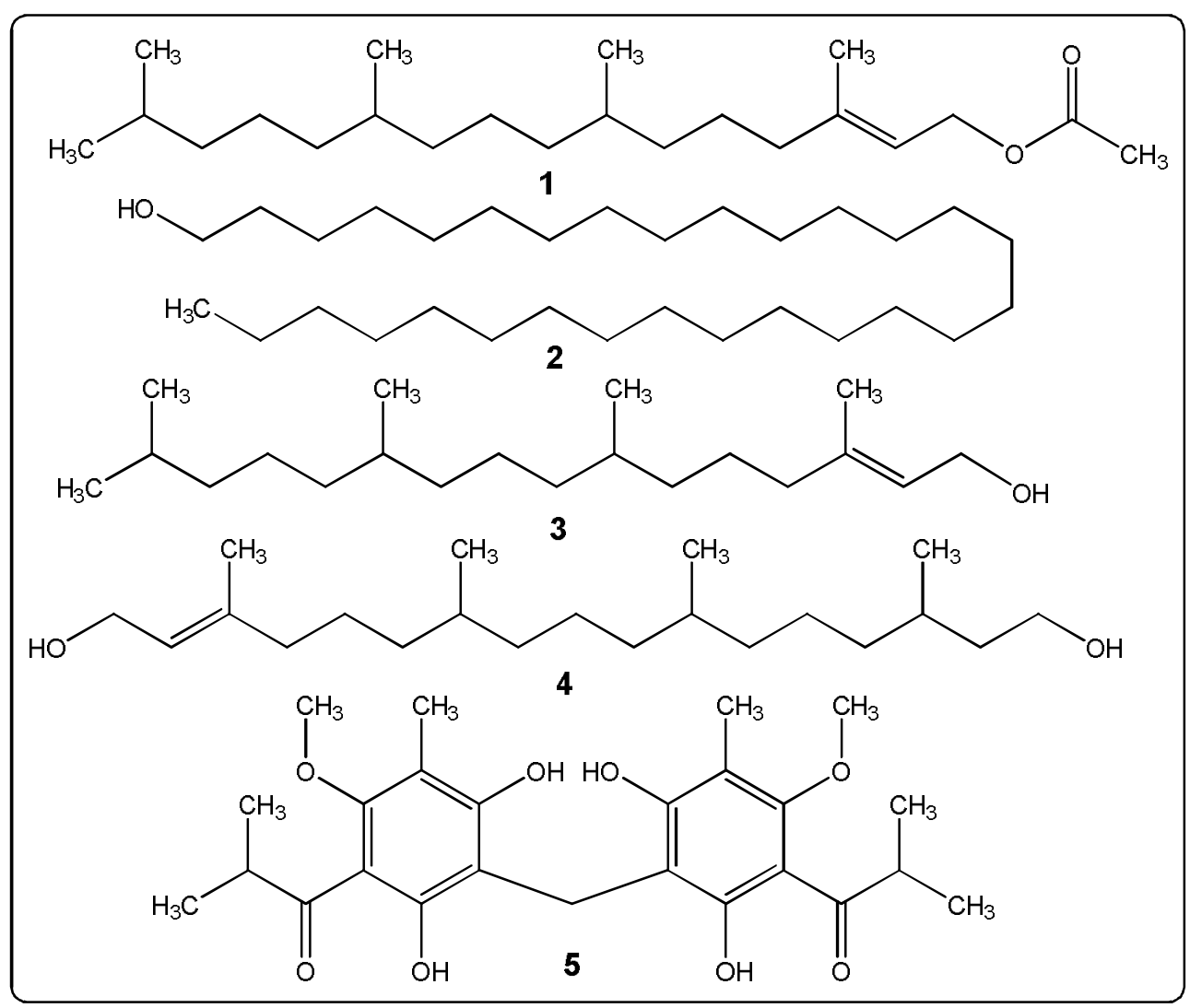

On the basis of identical chemical shift values as well as in DEPT and HMBC signals, compound $\mathbf{4}$ was found to be almost related to compound $\mathbf{3}$. The cross-signals in the proton spectrum showed a two proton triplet at $\delta 3.62(J=6)$ and a carbon spectrum signal which appeared at $\delta 63.9$ evidenced a hydroxyl group bearing carbon. The protons that appeared at $\delta$ 
3.62 were found strongly attached to the carbon signal at $\delta 63.9$ as evidenced in the HSQC spectrum. The proton $\mathrm{H}-17$ at $\delta 3.62$ was found to be correlated with $\mathrm{C}-15$ in hetero-nuclear multiple bond coherence. Hence, a new phytol analogue $(E)-3,7,11,15$-tetramethylheptadec2-ene-1,17-diol, was identified from the combined spectral analysis of compound 4. To the best of our knowledge this is the new compound which has been isolated first time from the plant L. sericea.

\subsection{Antibacterial bioassay}

The antibacterial activity of ethanol extracts of $L$. sericea and isolated compounds have been summarised in Table 1 . The ethanol extract of $L$. sericea inhibited the bacterial growth and exhibited noteworthy MIC value of $15.6 \mu \mathrm{g} / \mathrm{mL}$. Compound 5 was found to be the most active compound against $P$. acnes with MIC value of $1.9 \mu \mathrm{g} / \mathrm{mL}$ as compared to tetracycline (positive control) with MIC value of $3.1 \mu \mathrm{g} / \mathrm{mL}$. It is worth noting that threshold MIC values of 100 and $10 \mu \mathrm{g} / \mathrm{mL}$ have been recommended for plant extracts and pure compounds, respectively, to rate them as having significant antimicrobial activity (Kuete, 2010). Thus the MIC values measured for the activity of crude extract and compound 5 can be considered significant. Compounds 1-4 did not show any growth inhibitory activities at highest concentration tested $(500 \mu \mathrm{g} / \mathrm{mL})$. To the best of our knowledge, the antibacterial activity of $L$. sericea and isolated compounds (1-5) against $P$. acnes is being reported for the first time. However, petroleum ether and dichloromethane leaves extract of $L$. sericea was found to be active against Bacillus subtilis and Staphylococcus aureus, respectively, with MIC value of $0.025 \mathrm{mg} / \mathrm{mL}$ (Aremu et al., 2010). In the present study no activity for compound $\mathbf{2}$ and $\mathbf{3}$ was found. Contrary to this, in a study, compound $\mathbf{3}$ exhibited activity against Mycobacterium tuberculosis and M. avium with MIC values of 2 and $16 \mu \mathrm{g} / \mathrm{mL}$, respectively (Rugutt and Rugutt, 2012); and compound 2 showed antibacterial activity against Escherichia coli, Staphylococcus aureus, Bacillus cereus and Lactobacillus 
acidophilus with MIC values ranging between 0.01-0.1 $\mu \mathrm{g} / \mathrm{mL}$ (Upadhyay et al., 2010). Based on literature search, no antimicrobial activity of compound $\mathbf{1}$ and $\mathbf{5}$ was found.

\subsection{Transmission electron microscopy (TEM)}

For microscopy studies, the plant extract and compound $\mathbf{5}$ which showed activity against the bacteria were selected. The TEM micrograph represents clear differences between untreated and treated $P$. acnes. The untreated $P$. acnes showed normal morphological characters with distinct cell wall which was long, spindle shaped, smooth and lined with cell membrane. A centrally located nucleoid surrounded by ribosomes was observed (Fig 2a). The TEM micrograph showed cell injuries caused to $P$. acnes on exposure to the ethanol extract of $L$. sericea for 72 h. P. acnes treated with the ethanol extract of $L$. sericea at a concentration of $100 \mu \mathrm{g} / \mathrm{mL}$ exhibited abnormal changes in cell content material whereas at higher concentration of $300 \mu \mathrm{g} / \mathrm{mL}$, the cell wall of bacteria was found lysed and cell debris was observed (Fig 2b, 2c). Compound 5 caused significant damage to the cells of $P$. acnes at a concentration of $50 \mu \mathrm{g} / \mathrm{mL}$. The intracellular content was found to be effluxed due to breaks in the cell wall. The intact cells showed changes in the appearance of cell organelles. Due to extensive lysis of the bacteria, the debris was observed all over (Fig 2d). Tetracycline treated bacteria at a concentration of $50 \mu \mathrm{g} / \mathrm{mL}$, caused significant damages to the cells of $P$. acnes, leading to damages in the cell membrane, distortion in the cell structure and shrinkage of cell content material (Fig 2e). Treating P. acnes with DMSO at $2.5 \%$ exhibited no lethal effects to bacteria (Fig 2f). The TEM micrograph confirms the antibacterial activity of $L$. sericea and compound $\mathbf{5}$ against $P$. acnes.

\subsection{Antioxidant assay}

DPPH assay provides antiradical properties of the samples. The antioxidants are able to stable the free DPPH radical due to their proton donating ability. The scavenging effect of L. sericea ethanol extract and compound 5 on DPPH increased with their increasing concentrations. These samples showed very significant antioxidant activity with $\mathrm{IC}_{50}$ values 
Figure 2: Transmission electron micrograph of a thin section of $P$. acnes
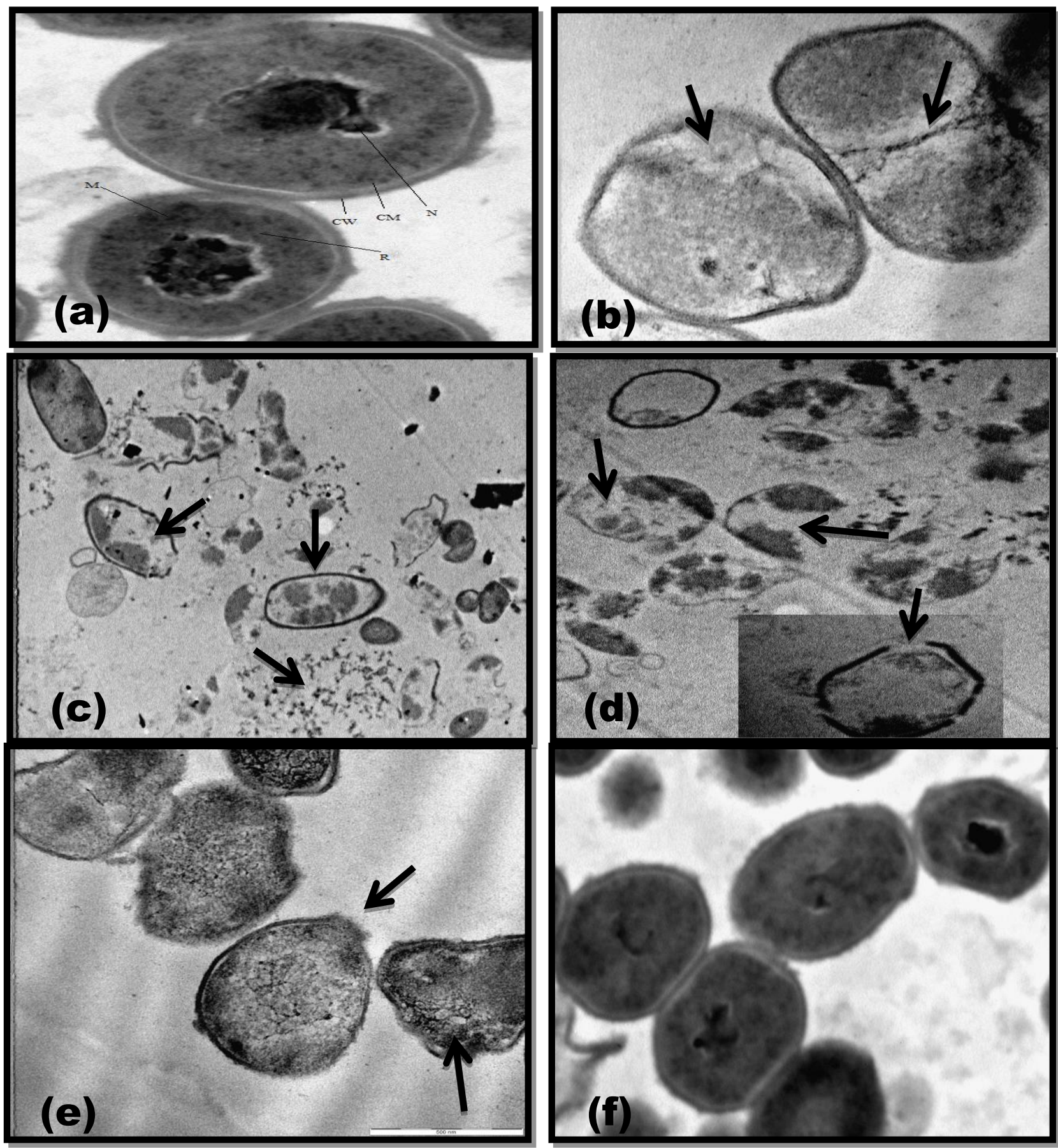

(a) untreated bacterias, labelled structures: cell wall (CW); cytoplasmic membrane (CM); nucleoid $(\mathrm{N})$; ribosomes $(\mathrm{R})$; mesosomes $(\mathrm{M}) \times 60 \mathrm{~K}$

(b) $P$. acnes treated with $L$. sericea at $100 \mu \mathrm{g} / \mathrm{ml} \times 60 \mathrm{~K}$

(c) P. acnes treated with L. sericea at $300 \mu \mathrm{g} / \mathrm{ml} \times 40 \mathrm{~K}$

(d) $P$. acnes treated with compound 5 at $50 \mu \mathrm{g} / \mathrm{ml} \times 50 \mathrm{~K}$

(e) P. acnes treated with positive control (tetracycline) at $50 \mu \mathrm{g} / \mathrm{ml} \times 60 \mathrm{~K}$

(f) $P$. acnes treated with solvent (DMSO at 2.5\%) x $60 \mathrm{~K}$. The arrows indicate cell injuries to the $P$. acnes. 
very similar to Vitamin $\mathrm{C}$, a widely used antioxidant compound. The results are shown in Table 1. The mg vitamin $\mathrm{C}$ equivalents/g dry weight for compound $\mathbf{5}$ was calculated to be 392. Compounds 1-4 did not show any antioxidant activity. Concerning the structure-activity relationship, it was clear that the presence of four free hydroxyl groups in compound $\mathbf{5}$ could be responsible for its antioxidant activity in comparison with compounds 1-4 which possesses less or lacks any free hydroxyl groups. Similar to our results, it has been reported that the methanol extract of the leaves of $L$. sericea exhibited antioxidant activity with $\mathrm{IC}_{50}$ value of $3.0 \mu \mathrm{g} / \mathrm{mL}$. However, petroleum ether and DCM extract exhibited a higher $\mathrm{IC}_{50}$ value of 26.2 and $27.7 \mu \mathrm{g} / \mathrm{mL}$, respectively (Aremu et al., 2010). To the best of our knowledge, this is the first report of DPPH scavenging activity of all the compounds isolated in this study.

\subsection{In vitro cytotoxicity assay}

The cytotoxicity of the extracts and compound 2, 3 and $\mathbf{5}$ was done on B16-F10 mouse melanocytes and U937 human macrophage cells. The cytotoxicity analysis of compounds 1 and $\mathbf{4}$ was not conducted due to unavailability of sufficient amount of the samples. All the results are listed in Table 1. To the best of our knowledge, the cyotoxicity in the present study of the ethanol extract of $L$. sericea and three isolated compounds against B16-F10 mouse melanocytes and U937 human macrophage cells is reported for the first time. L. sericea exhibited moderate toxicity on B16-F10 cells and comparatively higher toxicity on U937 cells. Compound $\mathbf{5}$ showed significant toxicity on both the cell lines with $\mathrm{EC}_{50}$ value of $<3.12 \mu \mathrm{g} / \mathrm{mL}$. However, compound $\mathbf{2}$ and $\mathbf{3}$ did not exhibit any toxicity on both the cell lines with $100 \%$ viability of cells at their highest concentration of $100 \mu \mathrm{g} / \mathrm{mL}$. Similar to our findings, strong cytotoxic effects of compound $\mathbf{5}$ against MAC tumour cells with $\mathrm{EC}_{50}$ value of $1.5 \mu \mathrm{g} / \mathrm{mL}$ was reported by Woldemariam et al. (1992). Compound 2 was reported as nontoxic constituent of Viburnum jucundum (Rios et al., 2001). Compound 3 showed toxicity against skin cancer cells (SK-MEL-2), CNS cancer cells (XF498) and colorectal cancer cells 
(HCT15) with $\mathrm{EC}_{50}$ values ranging from 6.2-11.2 $\mu \mathrm{g} / \mathrm{mL}$ (Sung et al., 1999). No reports in the literature about the cell toxicity have been found for L. sericea.

\subsection{Anti-inflammatory activity}

P. acnes stimulate macrophages for increased production of pro-inflammatory cytokines such as IL 8 and TNF $\alpha$ which contributes to the induction of mediators of inflammatory response. In the present study, IL 8 and TNF $\alpha$ were used as major criteria for evaluation of anti-inflammatory activity. The U937 cells co-cultured with $P$. acnes caused an increase in the production of IL 8 and TNF $\alpha$ (Fig 3a). To test the anti-inflammatory effects of $L$. sericea, Figure 3: (a) Dose-dependent inhibition of IL 8 and TNF $\alpha$ by ethanol extract of Leucosidea sericea; (b) Differential response of pentoxifylline on the release of IL 8 and TNF $\alpha$ by U937 cells infected with $P$. acnes.
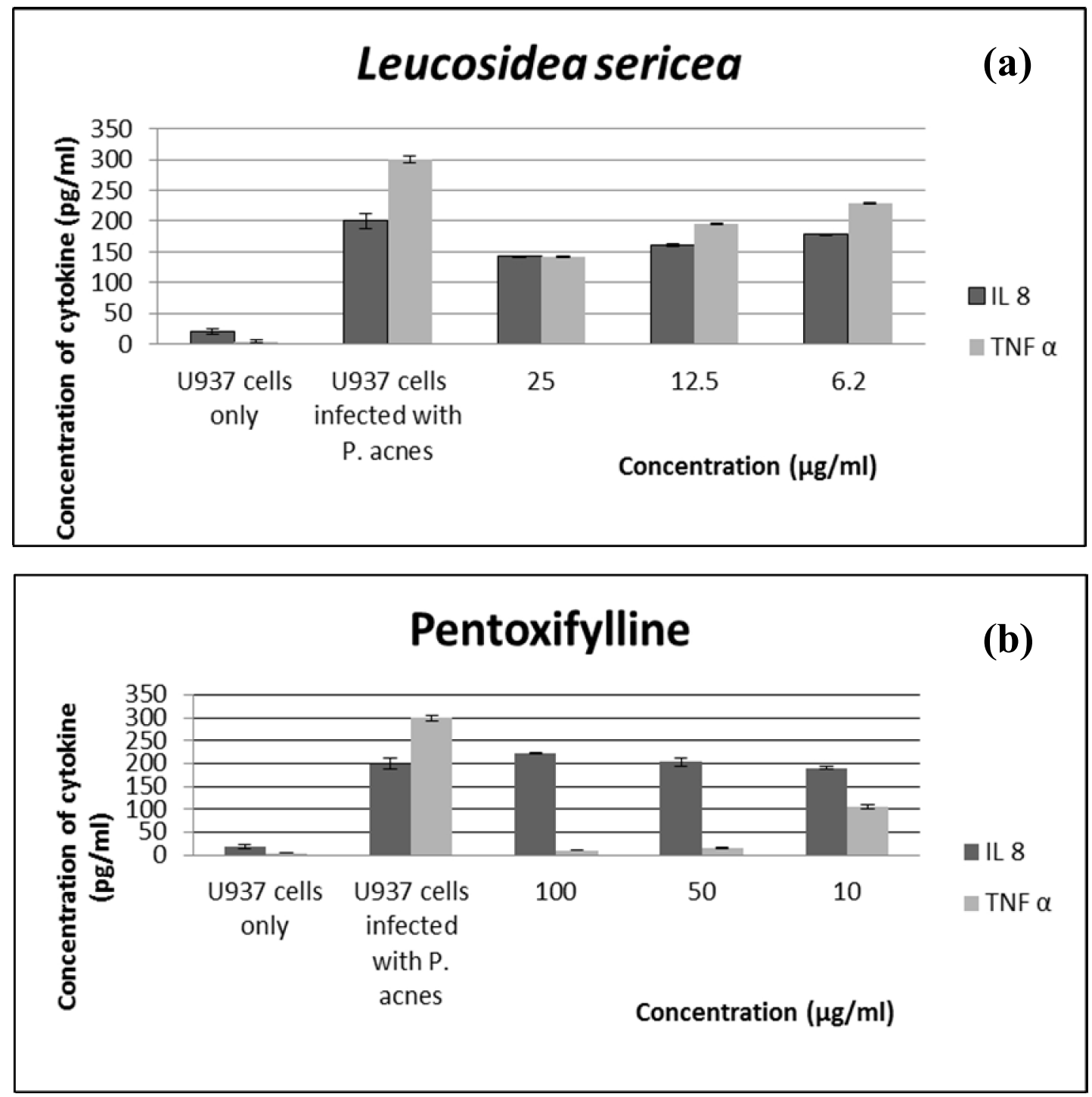
an in vitro screening at three nontoxic concentrations were applied. As shown in Fig 3a, the ethanol extract of $L$. sericea decreased the production of IL 8 and TNF $\alpha$ in dose-dependent manner. Furthermore, the plant extract did not increase the secretion of either of the cytokines in culture of U937 cells in the absence of heat killed P. acnes (data not shown). Pentoxifylline which was used as a control behaves differently on the cytokines. Based on previous reports, it down regulated the secretion of TNF $\alpha$ and caused no change in IL 8 release (D’Hellencourt et al., 1996). As shown in Fig 3b, our results were in agreement with other researchers. Significant inhibition of TNF $\alpha$ was observed at 100 and $50 \mu \mathrm{g} / \mathrm{mL}$ of pentoxifylline whereas, no change in IL 8 concentration was observed. To the best of our knowledge, no reports about L. sericea in context with suppression of cytokines were found. Although, similar to our results, other plants i.e. Eucommia ulmoides and Ilex paraguariensis extracts were reported to reduce the secretion of IL 8 and TNF $\alpha$ in human monocytic THP-1 cells pre-treated with $P$. acnes at concentration of $0.1 \mathrm{mg} / \mathrm{mL}$ (Tsai et al., 2010).

\section{Materials and Methods}

\subsection{General}

Column chromatography: silica gel 60 (70-230 mesh, Sigma-Aldrich). Sephadex LH-20 (Sigma-Aldrich). Propionibacterium acnes (P.acnes): ATCC 11827 (Anatech Company, Johannesburg). Cell proliferation Kit II: XTT (Roche diagnostics Pty Ltd., Johannesburg). All the cell lines and medium (Highveld Biological Pty Ltd, Johannesburg). Elisa kit and reagents (BD Biosciences, Johannesburg). All the chemicals were purchased from SigmaAldrich and Merck SA Pty Ltd.

\subsection{Plant material}

The twigs and leaves of $L$. sericea were collected from the botanical garden of University Of Pretoria, Pretoria, in March 2011. A voucher specimen (PRU 119052) was 
deposited at H.G.W.J Schwelckerdt Herbarium, Department of Plant Science, University of Pretoria, Pretoria.

\subsection{Extraction and isolation}

The air-dried and powdered leaves $(2.3 \mathrm{~kg})$ were soaked in $9 \mathrm{~L}$ of ethanol for 3 days at room temperature. The filtrates were collected and concentrated under reduced pressure by a rotavapor at $40{ }^{\circ} \mathrm{C}$ to produce $73 \mathrm{~g}$ of crude ethanol extract. About $60 \mathrm{~g}$ of the ethanolic extract of $L$. sericea was subjected to silica gel column chromatography $(70 \mathrm{~cm} \times 120 \mathrm{~cm}$ ) with hexane fraction (Hex): ethyl acetate (EtOAc) mixtures of increasing polarity (100:0 to 0:100) followed by $100 \%$ methanol $(\mathrm{MeOH})$ as eluent. In total 51 fractions $(500 \mathrm{~mL})$ were collected and similar fractions were combined according to thin-layer (TLC) profile, which resulted into 20 major fractions (MF). All the 20 major fractions were tested for antibacterial activity using broth dilution method against pathogenic $P$. acnes. The results are shown in Table 1 . Fractions $6,10,15$ and 16 showed inhibitory activity against $P$. acnes; hence were subjected further to chromatographic columns to isolate the bioactive compounds. MF 6 (600 mg) was separated on a silica gel column eluted with Hex: dichloromethane (DCM) mixtures of increasing polarity (100:0 to 0:100) which yielded twenty three sub fractions (Sf). Sf 3-5 led to the isolation of compound 1 (6 mg, 0.01\%), Sf 7-8 eluted compound 2 (10 mg, 0.02\%) and Sf 9-12 led to the separation of compound $3(9 \mathrm{mg}, 0.02 \%)$ and compound $4(8 \mathrm{mg}$, $0.01 \%)$ was obtained from Sf $13-14$. The separation of MF 10 (1.4 g) was done using silica gel column chromatography eluting with mixture of Hex: (DCM: MeOH:: 99:1) in equal ratio, which yielded forty six Sf. Sf 4 and 5 were combined according to TLC analysis, consequently compound 5 (34 mg, 0.06\%) was obtained. Further, MF 15 and 16 (2.3 g) were combined based on TLC profile and were separated similar to MF 10, which yielded one hundred and forty Sf. From the Sf. 46-51, compound 5 (15 mg, 0.03\%) was obtained for the second time. 


\subsection{Characteristic data of compound 4}

(E)-3,7,11,15-tetramethylheptadec-2-ene-1,17-diol (compound 4): Colourless oil; UV $\left(\mathrm{CDCl}_{3}\right) \lambda_{\max }(\log \varepsilon) 217 \mathrm{~nm}$; IR (KBr) $v_{\max }: 3417,3300,2954,2923,2849,1462,1384 \mathrm{~cm}^{-1}$. ${ }^{1} \mathrm{H}$ NMR $\left(200 \mathrm{MHz}, \mathrm{CDCl}_{3}, \delta\right.$ in ppm, $J$ in $\left.\mathrm{Hz}\right): \delta_{\mathrm{H}} 5.43(1 \mathrm{H}, t, J=8), 4.12(2 \mathrm{H}, d, J=8)$, $3.62(2 \mathrm{H}, t, J=6) 2.01(2 \mathrm{H}, 2 \mathrm{x}-\mathrm{OH}), 1.97(2 \mathrm{H}, t, J=8), 1.65(3 \mathrm{H}, \mathrm{s}, \mathrm{H}-20), 1.37-1.13(16 \mathrm{H}$, $\left.\mathrm{m}, \mathrm{CH}_{2}\right), 0.86-0.83\left(9 \mathrm{H}, 3 \mathrm{x}-\mathrm{CH}_{3}\right) .{ }^{13} \mathrm{C} \mathrm{NMR}\left(50 \mathrm{MHz}, \mathrm{CDCl}_{3}\right): \delta_{\mathrm{C}} 141.2(\mathrm{C}-3), 123.9(\mathrm{C}-2)$, 63.9 (C-17), 60.2 (C-1), 40.7, 40.2, 38.2, 37.5, 33.6, 33.5, 32.7, 30.5, 30.4, 28.8, 25.9, 25.6, 25.3, 23.5, 23.4, 20.6, 17.0. HREIMS $[\mathrm{M}+\mathrm{H}]^{+} \mathrm{m} / \mathrm{z}$ 327.3021 (calcd. for $\mathrm{C}_{21} \mathrm{H}_{42} \mathrm{O}_{2}+\mathrm{H}$, 327.3017 required 326 for $\mathrm{C}_{21} \mathrm{H}_{42} \mathrm{O}_{2}$ ).

\subsection{Antibacterial bioassay}

The ethanol extract and compounds were tested against $P$. acnes by determining the minimum inhibitory concentration (MIC) values obtained by a broth dilution method as previously described by Mapunya et al. (2011) with few modifications. Briefly, the bacteria was cultured from a Kwik-Stick on nutrient agar and incubated at $37^{\circ} \mathrm{C}$ for $72 \mathrm{~h}$ under anaerobic conditions before the assay. The $72 \mathrm{~h}$ culture of the bacteria was dissolved in nutrient broth and the suspension was adjusted to 0.5 McFarland standard turbidity. This resulted in $10^{5}-10^{6}$ colony forming units $(\mathrm{CFU}) / \mathrm{mL}$. In a sterile 96 -well plate, $100 \mu \mathrm{L}$ of samples from the stock solution consisting of the plant extract/ isolated compounds $(2 \mathrm{mg} / \mathrm{mL}$ in $10 \%$ dimethyl sulphoxide (DMSO)) and the positive control tetracycline $(0.2 \mathrm{mg} / \mathrm{mL})$ was diluted with broth. Twofold serial dilutions were made in broth over a range to give concentrations of 500-3.9 $\mu \mathrm{g} / \mathrm{mL}$ and $50-0.3 \mu \mathrm{g} / \mathrm{mL}$ for the plant extract/ isolated compounds and positive control tetracycline, respectively. The bacterial suspension $(100 \mu \mathrm{L})$ was added to the wells. The wells with $2.5 \%$ DMSO and bacterial suspension without samples served as the solvent and negative controls respectively. The plates were incubated at $37^{\circ} \mathrm{C}$ for $72 \mathrm{~h}$ in an anaerobic environment. The MIC value was determined by observing colour change in the 
wells after addition of 2-(4-iodophenyl)-3-(4-nitrophenyl)-5-phenyl (INT) (defined as the lowest concentration that showed no bacterial growth).

\subsection{Transmission electron microscopy (TEM)}

The TEM procedures followed the protocol of a previous publication (Pan et al., 2009). Briefly, bacterial was concentrated by centrifugation at $10000 \mathrm{rpm}$ for $1 \mathrm{~min}$. The pellet was resuspended in nutrient broth to a final OD550 $\mathrm{nm}$ of 1 . The concentrations of plant extract were 1.3 and 4 times of its MIC; and 5 times of MIC for pure compound in order to visualise the lethal effects of tested samples against bacteria. The bacterial suspension $(5 \mathrm{~mL})$ was mixed with plant extract and pure compound to a final concentration of 300 and $100 \mu \mathrm{g} / \mathrm{mL}$ for plant extracts and $50 \mu \mathrm{g} / \mathrm{mL}$ for pure compound. Tetracycline $(50 \mu \mathrm{g} / \mathrm{mL})$ and DMSO $(2.5 \%)$ were used as positive and solvent control. The pathogen was treated for $72 \mathrm{~h}$; the control group consisted of only bacterial suspension in nutrient broth. Controls, treated and untreated $P$. acnes cultures were centrifuged and fixed in $2.5 \%$ glutraldehyde in phosphate buffer at room temperature for $1 \mathrm{~h}$. Samples were washed with phosphate buffer and postfixed in both $1 \%$ osmium tetraoxide and uranyl acetate. The cells were dehydrated in ethanol and embedded in quetol resin. Thin sections were prepared with a microtome and micrographs were taken using a JEOL JEM-2100F field emission electron microscope.

\subsection{Antioxidant assay}

Antioxidant activity of the ethanol extract of L. sericea and purified compounds was investigated using 1, 2-diphenyl-1-picrylhydrazyl (DPPH) antioxidant assay. Following the procedures as described by DuToit et al. (2001) for each sample, a dilution series (8 dilutions) was prepared in a 96 well plate by adding distilled water as a dilution medium. Final concentration of the samples ranged from 100 to $0.7 \mu \mathrm{g} / \mathrm{mL}$. Each concentration was tested in triplicates. Vitamin $\mathrm{C}$ was used as a positive control. The radical scavenging capacities of the samples was determined using a BIOTEK plate reader to measure the disappearance of DPPH at $550 \mathrm{~nm}$. The radical scavenging activity was measured in terms of 
the amount of antioxidants necessary to decrease the initial DPPH absorbance by $50 \%\left(\mathrm{IC}_{50}\right)$. The $\mathrm{IC}_{50}$ value of each sample was determined graphically by plotting the absorbance of DPPH as a function of the sample concentration in $\mu \mathrm{g} / \mathrm{mL}$. The $\mathrm{IC}_{50}$ is the amount of antioxidant necessary to decrease the initial DPPH absorbance by $50 \%$. The results were calculated using the following equation:

$$
\mathrm{AA} \%=\left\{\mathrm{Abs}_{\text {blank }}\left(\mathrm{Abs}_{\text {sample }}-\mathrm{Abs}_{\text {control }}\right) / \mathrm{Abs}_{\text {blank }}\right\} \times 100
$$

The $\mathrm{mg}$ vitamin $\mathrm{C}$ equivalents/g dry weight of potent samples was calculated as follows:

$$
\operatorname{VitEAC}(\mathrm{mg} \mathrm{AA} / 100 \mathrm{~g})=\left(\mathrm{IC}_{50}(\text { vit c }) / \mathrm{IC}_{50}(\text { sample })\right) \times 1000 .
$$

\subsection{In vitro cytotoxicity assay}

The mouse melanocytes (B16-F10) cells were cultured in a complete Minimum Essential Eagle's Medium (MEM) whereas the human U937 cells were cultured in Roswell Park Memorial Institute (RPMI) containing 10\% fetal bovine serum (FBS) and 1\% gentamycin. B16-F10 (10 cells per well) and U937 (10 cells per well) were seeded into a 96-well plate. After an overnight incubation at $37{ }^{\circ} \mathrm{C}$ in $5 \% \mathrm{CO}_{2}$ and a humidified atmosphere, the extract, compounds and the positive control (actinomycin D) were added to the cells. The final concentrations of plant extract and pure compounds were ranging from $400-3.13 \mu \mathrm{g} / \mathrm{mL}$ and $100-1.5 \mu \mathrm{g} / \mathrm{mL}$, respectively. The highest concentration of positive control $(0.05 \mu \mathrm{g} / \mathrm{mL})$ was serially diluted to eight consecutive wells. The plate was then incubated at $37^{\circ} \mathrm{C}$ in $5 \% \mathrm{CO}_{2}$, and a humidified atmosphere after which the toxicity effects of the extracts was assayed using the XTT (sodium 3'-[1-(phenyl amino-carbonyl)-3,4-tetrazolium]-bis-[4-methoxy-6nitrobenzene sulfonic acid hydrate) cytotoxicity assay. Fifty micro litres of XTT reagent (1 $\mathrm{mg} / \mathrm{mL}$ XTT with $0.383 \mathrm{mg} / \mathrm{mL}$ PMS) was added to the wells and incubated for $1 \mathrm{~h}$. The optical densities of the wells were measured at $450 \mathrm{~nm}$ (690 nm reference wavelength) using BIOTEK Power-wave XS multi well reader (A.D.P., Weltevreden Park, South Africa). By referring to the control (medium with DMSO), the cell survival rate was assessed. The 
'Graph Pad Prism 4', statistical program was used to analyse the 50\% inhibitory concentration $\left(\mathrm{EC}_{50}\right)$ values.

\subsection{Preparation of heat-killed P. acnes and measurement of cytokine production}

The effect of plant extract on cytokine production (IL 8 and TNF $\alpha$ ) was evaluated using enzyme immunoassay kits (ELISA) using method as described previously (Tsai et al., 2010). Briefly, the log phase culture of $P$. acnes was harvested, washed three times with phosphate buffer saline (PBS), and incubated at $80^{\circ} \mathrm{C}$ for $30 \mathrm{~min}$ to kill the bacteria. The heat-killed bacteria were stored at $4{ }^{\circ} \mathrm{C}$ until use. The human U937 cells were seeded at $10^{6}$ cells per well in a $24-w e l l$ plate and was stimulated with heat killed P. acnes (wet weight $100 \mu \mathrm{g} / \mathrm{mL}$ ) alone and in combination with the different test samples. Pentoxifylline was used as a control. After $18 \mathrm{~h}$ incubation, the cell-free supernatants were collected and the concentrations of IL 8 and TNF $\alpha$ were analysed. Cytokine standards were serially diluted to facilitate the construction of calibration curves necessary for determining protein concentration of test samples.

\section{Acknowledgements}

The authors thank University of Pretoria and National Research Foundation for the financial grants.

\section{Conflict of interests}

The authors declare that they have no conflict of interests.

\section{References}

Aremu, A.O., Fawole, O.A., Chukwujekwu, J.C., Light, M.E., Finnie, J.F., Van Staden, J., 2010. In vitro antimicrobial, anthelmintic and cyclooxygenaseinhibitory activities and phytochemical analysis of Leucosidea sericea. J. Ethnopharmacol. 131, 22-27. 
Aremu, A.O., Amoo, S.O., Ndhlala, A.R., Finnie, J.F., Van Staden, J., 2011. Antioxidant activity, acetylcholinesterase inhibition, iridoid content and mutagenic evaluation of Leucosidea sericea. Food Chem. Toxicol. 49, 1122-1128.

Arican, O., Kurutas, E.B., Sasmaz S., 2005. Oxidative stress in patients with acne vulgaris. Mediators Inflamm. 6, 380-384.

Bosman, A.A., Combrinck, S., Roux-van der Merwe, R., Botha, B.M., McCrindle, R.I., 2004. Isolation of an anthelmintic compound from Leucosidea sericea. S. Afr. J. Bot. 70, $509-511$.

Chomnawang, M.T, Surassmo, S., Nukoolkarn, V.S., Gritsanapan, W., 2005. Antimicrobial effects of Thai medicinal plants against acne-inducing bacteria. J. Ethnopharmacol. $101,330-333$.

Coenye, T., Brackman, G., Rigole, P., Witte, E.D., Honraet, K., Rossel, B., Nelis, H.J., 2012. Eradication of Propionibacterium acnes biofilms by plant extracts and putative identification of icariin, resveratrol and salidroside as active compounds Phytomedicine 19, 409-412.

D’Hellencourt, C.L., Diaw, L., Cornillet, P., Guenounou, M., 1996. Differential regulation of TNF $\alpha$, IL-1 $\beta$, IL-6, IL-8, TNF $\beta$ and IL-10 by pentoxifylline. Int. J. Immunopharmac. $18,739-748$.

Du Toit, R., Volsteedt, Y., Apostolides, Z., 2001. Comparison of the antioxidant content of the fruits, vegetables and teas measured as Vitamin C equivalents. Toxicology 166, 63-69.

Fouche, G., Cragg, G.M., Pillay, P., Kolesnikova, N., Maharaj, V.J., Senabe, J., 2008. In vitro anticancer screening of South African plants. J. Ethnopharmacol. 119, 455-461.

Itoh, D., Kawano, K., Nabeta, K., 2003. Biosynthesis of chloroplastidic and extrachloroplastidic terpenoids in liverwort cultured cells: ${ }^{13} \mathrm{C}$ serine as a probe of 
terpene biosynthesis via mevalonate and non-mevalonate pathways. J. Nat. Prod. 66, 332-336.

Kuete, V., 2010. Potential of cameroonian plants and derived-products against microbial infections. A review. Planta Med. 76, 1479-1491.

Leydon, J.J., 1997. Therapy for Acne vulgaris. The New England J. Med., 1156-1162.

Mapunya, M.B., Hussein, A.A., Rodriguez, B., Lall, N., 2011. Tyrosinase activity of Greyia flanaganii (bolus) constituents. Phytomedicine 18, 1006-1012.

Nair, J.J., Aremu, A.O., Van Staden J., 2012. Anti-inflammatory effects of Leucosidea sericea (Rosaceae) and identification of the active constituents. S. Afr. J. Bot. 80, 7576.

Pan, C.Y., Chen, J.Y., Lin, T.L., Lin, C.H., 2009. In vitro activities of three synthetic peptides derived from epinecidin-1 and an anti-lipopolysaccharide factor against Propionibacterium acnes, Candida albicans, and Trichomonas vaginalis. Peptides 30, 1058-1068.

Rios, M.Y., Gonzalez-Morales, A., Villarreal, L., 2001. Sterols, triterpenes and biflavonoids of Viburnum jucundum and cytotoxic activity of ursolic acid. Planta Med. 67, 683684.

Rugutt, J. K., Rugutt, K.J., 2012. Antimycobacterial activity of steroids, long-chain alcohols and lytic peptides. Nat. Prod. Res. 26, 1004-1011.

Shaw, L., Kennedy, C., 2007. The treatment of acne. J. Paediatr. Child Health 17, 385-389.

Sung, J.H., Lee, J.O., Son, J.K., Park, N.S., Kim, M.R., Kim, J.G., Moon, D.C., 1999. Cytotoxic constituents from Solidago virga-aurea var. gigantea MIQ. Arch. Pharm. Res. 22, 633-637.

Tsai, I.L., Cheng, M.J., Hung, H.W., Cheng, H.I., Chen, I.S., 2007. Chemical constituents from the leaves of Litsea acutivena. J. Chinese Chem. Soc. 54, 503-506. 
Tsai, T.H., Tsai, T.H., Wu, W.H., Tseng, J.P., Tsai, P.J., 2010. In vitro antimicrobial and anti-inflammatory effects of herbs against Propionibacterium acnes. Food Chem. 119, 964-968.

Upadhyay, R.K., Ahmad, S., Tripathi, R., Rohtagi, L., Jain, S.C., 2010. Screening of antimicrobial potential of extracts and pure compounds isolated from Capparis decidua. J. Med. Plant Res. 4, 439-445.

Van Wyk, B., Van Wyk, P., Van Wyk, B.E., 2008. Photo Guide to Trees of Southern Africa. Briza Publications, Pretoria, South Africa.

Woldemariam, T.Z., Fell, A.F., Linley, P.A., Bibby, M.C., Phillips, R.M., 1992. Evaluation of the anti-tumour action and acute toxicity of kosins from Hagenia abyssinica. J. of Pharmaceut. Biomed. Anal. 10, 555-560. 